\title{
A Role of Digital Media on Discussing about the Diplomacy in the World
}

\author{
Amirhossein Asadi* \\ Payame Noor University, Tehran, Iran \\ Email: Assedy@yahoo.com
}

How to cite this paper: Asadi, A. (2017). A Role of Digital Media on Discussing about the Diplomacy in the World. Open Journal of Political Science, 7, 267-275.

https://doi.org/10.4236/ojps.2017.72021

Received: December 6, 2016

Accepted: April 17, 2017

Published: April 20, 2017

Copyright $\odot 2017$ by author and Scientific Research Publishing Inc. This work is licensed under the Creative Commons Attribution International License (CC BY 4.0).

http://creativecommons.org/licenses/by/4.0/

\begin{abstract}
It is very important to understand the nature of digital media and its various categories and the position of this media and modern communication technology in the present social and political interactions. Explaining different kinds of discourses and different principles, theories, and conceptual models of the society along with the role of digital media is one of the most effective tools of information and culture in introducing the political system of Islamic Republic of Iran which is a religious democracy. A religious democracy is one of the aims of this study. In this study, a role of digital media in discourses of Islamic revolution was identified with a descriptive method. Also, there is no boundary in the virtual space. Therefore, relevant articles and studies were published about digital media and virtual diplomacy during the years of 2009 to 2013. Also, some of the relevant scientific books were studied. Digital diplomacy is a new tool in the world, to change attitudes and influence the thinking and beliefs of people today without invasion and war. In this context, digital media, because of the exceptional features like power to influence public opinion, international and cross-border charm and diversity, have great influence on the shaping of social changes and changing discourses. Hence development programs of making discourse using digital media, civil society and the international community can contribute to the development of the religious discourse of democracy. In this article, digital media and their effectiveness and usage in an introductory and discussion process were posed. Since people's ideas are influenced a lot with digital media, digital media have a lot of effects on forming the social developments and discourse changes. Therefore, developing discourse programs with the use of digital media in internal and international communities can be effective in the development of Islamic revolution discourse.
\end{abstract}

\section{Keywords}

Media, Digital Media, Diplomacy, Discourse

\footnotetext{
${ }^{\star}$ Graduate Student of Political Science, Payame Noor University, Tehran West, Tehran, Iran.
} 


\section{Introduction}

Digital discourse which is a new kind of discourse tool and is included of modern components is made with a development of information technology. This kind of discourse is along with a message transfer rate, distance remove, informing people, effectiveness, information combination, social contributions, subcultures, and other cases. A first purpose of this study is to identify the nature of digital media and its various categories and the position of these media and modern communication technologies in nowadays social and political interactions. A second purpose of this study is to examine different concepts and methods of discourse, and global theories and mental models of discourse. In this study, discourse processes and the role of media in discourse are stated. A third purpose of this study is to examine the role of digital media as the most effective and modern means of information and culture in introducing the political system of Islamic Republic of Iran which is a religious democracy. In this study, a religious democracy and its literature review were stated.

\section{Literature Review}

Good studies were done in the world and specially, in the countries of digital technologies like America toward digital media, virtual space, and their roles in virtual diplomacy. Also, a lot studies were conducted toward the position of media in the modern world. Nevertheless, there are less articles about the role of digital media on discussing about culture and discourse (Ameli, 2003).

Also, there are valuable books and articles toward this subject. Among these books and articles, we can point out to the cyberculture engineering book by $\mathrm{Dr}$. Mohammad Hossein Taghdisi. In this book, an author stated completely about the principles of the cyberspace and an engineering process of the virtual space as well as their different roles on the life style, community identity, policy, and communications. The author of this book believes that nowadays, human begins who inhabit in different places are one community because they communicate and share information with each other all the time (Ameli, 2010).

Another valuable book in this domain is about the critical studies of virtual colonization of America by Saeed Reza Ameli. In this book, an author pointed out to this case that America spent different eras during its virtual colonization.

In the old colonial period, the world was dominated by Europe through exploration, war, hard power and political colonialism techniques, but in the next era which was interpreted as neo-colonial period, people's culture and ideas were dominated through cultural and economic policies.

In the virtual colonial period, United States was at the head of colonizing other countries. Since the first purpose of America in colonizing other countries was to destroy people and communities' idea, soft power was used in this period for the purpose of not giving right to people of America to vote (Azimi, 2013).

\subsection{Methodology}

A design of this study is descriptive. First, the existent condition of this study 
was described for the purpose of identifying the research results. Therefore, this study is theoretical and wants to state the role of digital media on discussing about the religious diplomacy in the world. Therefore, the role of media on discussing about the religious diplomacy was analyzed after the identification of its role on politics. Finally, the role of digital media on discussing about the theoretical framework of religious diplomacy was identified. In this line, data were extracted from the newest scientific books, special articles, and internal and external database during the years of 2009 to 2013. In this study, sites like SID, Inter Science, Science Direct, and google scholar were used by researchers for the purpose of accessing to the existent articles. In Iran, conducted studies toward this subject were obtained from the national library, theses and research design of Iran. Also, one interview was done electronically with two experts of this domain. Finally, the results were given.

\subsection{Religious Democracy}

Imam Khomeini who was the founder of religious democracy said that we were the followers of our nation's votes. It means that we do not have a right to impose something on the people of our nation. Also, this right is not given to us by God and our prophets.

The above mentioned points show that a word like republic is representative of citizens' rights, but a word like Islamic shows the religious duty and obligation.

Constitution in each country is based on people's will. In Iran constitution, all the principles specially, a fourth principle points out to Islamic republic of Iran.

\section{Digital Media}

When information is published through media which are equipped to digital processors, these kinds of media are called digital media. These kinds of media are included of online media which are based on a network like a worldwide web internet, telecommunication services such as multimedia messaging service (MMS) and short message service (SMS) and other forms of data exchange networks as well as media based on physical digital carriers such as media software packages, computer games, and so on.

An increasing development of information technology in the society and a tremendous growth of modern communication technologies in the world are done by people's investment on digital media (Moraveji \& Zarei, 2012: p. 6).

\subsection{Theories of Media Effectiveness}

\subsubsection{Structuration Theory}

In a structuration theory of Giddens, there is a combination between an interaction and structuralism. Giddens combined structure and interaction for the purpose of setting structuration concept.

An aim of Giddens is to make compatibility between an institutional structure and individual agency in the form of a combining model of a social theory. $\mathrm{He}$ states that present actions like buying, going to school, and so on are as a result 
of social structures.

\subsubsection{Use-Effect Theory}

Use-effect theory describes the cognitive processes which lead individuals toward behavioral options with the use of given contents. Therefore, this theory focuses on the individual options of special media or messages (Niko, 2001: p. $80)$.

\subsection{A Combination of Goffman and Bourdieu Theories}

In this study, Goffman and Bourdieu theories were combined by a researcher for the purpose of identifying the theoretical framework of this study. After looking at a Goffman theory, we could understand that an internet with its natural limitations made a new interaction framework for the purpose of making communications among people. Also, an internet makes new opportunities for the users. We can state a virtual description of users from their own behavioral and characteristic features in the social networks with regard to these points. One of the behavioural and characteristic features of people is to access to information sooner than other people. This feature shows that people wants to attract other people's support. When people's communications are not face to face, they can tell their private lives to each other more easily (Basirian \& Basirian, 2006).

\subsubsection{Digital Media and Religious Democracy}

Modern media which make a virtual space will give special contents to phenomena and behaviours with imagery.

Media put human beings in another era and world (Taghdisi, 2014: p. 151).

In other words, cyberspace will practically form new social, identity, and mental structures.

Some of the theorists believe that virtual spaces will simplify the presence of subculture groups into the world with different identities, activisms, and mindsets.

Virtual space will change the nature of social relationships of people. Virtual spaces and specially, social networks with expanding people's communications in all around the world have major roles on intellectual and political discourses of western countries.

These networks with designing intellectual systems of data analysis will identify audience's opinions and affect directly and indirectly the ideas of users.

It is very important that western countries do all their efforts in communicating with each other through digital media and develop their scientific and technological substructures.

Virtual space makes people to think critically about themselves, their life style, other people's life style, symbolic habits, and social and cultural symbolics.

Virtual space makes people to rethink, compare themselves with other people, compete, and criticize themselves (Motamednejad, 2012).

Virtual space will provide the following principles faster than other devices.

- Virtual space will make people to have social interaction simultaneously and 
non-simultaneously with available and non-available comparators.

- Virtual space will make people to face place and time limitations and unite scattered geographical spaces.

- Virtual space will make people become familiar with different actions, discourses and cultures. Also, it won't highlight the local differences.

- Virtual space will give this opportunity to people to go beyond the existent traditional boundaries in a real world. Therefore, people can reach to peace, security, and mental relief through reducing social problems.

- Virtual space will combine general and special domains and remove the boundaries of these two domains through ignoring the role of inequality in social facts.

- The most important point is that virtual spaces will make people face different spaces. Therefore, they will modify individual and collective identities and create a social action system.

In such a space, human beings and social activists are the fans of networking and grouping and can attend simultaneously in different roles and social situations (Holmes, 2005: p. 20). In the past, people talked with each other about the theoretical subjects in the meetings.

Now people state their idea very fast through informative websites including different languages, social networks, computer games, video sites, and weblogs. Due to the presence of virtual communities, studying the social networks with a political approach and analyzing computer games built in the communities were threatened intensely. In social communities, people at least have something in common in sharing information with each other. This task will make people create their identities which are changing all the time. Individuals' identity in virtual communities is a digital identity. Regions, local languages, countries, national cultures, and races do not identify the identity of people in virtual communities, but only temporary and limited benefits in a domain of different subjects will gather people and build their identities. In this space, the principles of Islamic revolution of Iran and their intellectual system can be stated with an intelligent and planned movement. In order to take advantage more from virtual spaces, it is necessary to strengthen the place of virtual space and Information technology more and more in the country and its system structures (Bell, 2001).

\subsubsection{Training Digital Literacy}

Training the members of our embassies is necessary for using communication and information technology and modern technology. First, the members of embassies should be familiar with media tricks for the purpose of identifying the universal political systems and remove threatens and challenges by identifying executive strategies (Giddens, 2000).

\subsubsection{Development of Planned Weblogs}

Weblog is one of the available tools for communication. In all around the world, weblogs are cheap, available, and useful. Also, Persian, Arabic, and English weblogs should be introduced in the form of database and become up to dated. 
Weblogs can be used in two ways. First, users can present indirectly in weblogs which are of high traffic and their subjects are about the political activities. Content discussions can be done in the form of comment or communicating with the owners of these weblogs to put their contents in their weblogs. Second, active and attractive weblogs should be created in the domain of Islamic political issues specially, a religious democracy than can be effective on different groups of people.

\subsubsection{News Discovery}

RSS will make users visit relevant internet sites easier than before. Also, the number of people who visit these sites is increased. News which is based on the principles of Islamic system can be presented in various categories in order to be attractive and usable for different ages and regions.

With this task, better news can be given to people by daily analyzing news and users' comments (Mac Koyl, 2003).

\subsubsection{Analysis of Users' Behavioral Information}

One of the main reasons of western countries' investment in internet technology is that they can analyze users' behavior and activity and plan for second hand information. Operators and politicians of internet sites and networks analyze and categorize information, design targeted and subjective graphs, and analyze users' information.

It is necessary for statesmen to do something for this valuable tool. To state the principles of Islamic revolution, audiences should be identified, categorized, and answered to their questions.

\subsection{Wiki Usage and Set up}

With regard to the freeness of article publication, making independent wikis in the domain of Islamic politics and religious democracy can make many audiences discuss in the internet. It should be considered that an environment of website 2 or an interaction environment of an internet is an open and free environment for studying and investigating ideas, a design of unique political ideas, cultural interactions, and making a new form of political relationships. These relationships are not based on the political rules of foreign countries and state agreements, but they are targeted final audiences very fast. Website 2 can be its own antithesis if thinkers and university professors have more effective presence in web space.

\subsubsection{Computer Games and Religious Democracy}

With regard to the grate use of cellphone, we can say that a cellphone is removed from the technical tools and is set in a political and social device.

With this revolution in communication technology, although this technology is neglected in relation to other traditional media technologies including radio, TV, and publications and modern technologies like internet, it was more effective than modern similar technologies like internet (Laughey, 2007). 


\subsubsection{Making Digital Content}

Usually, in a digital space, content is very important and should be prepared from universities and scientific centers. In order to define religious democracy in an accurate way and introduce its features, the history, aims, critics, theory principles, and the political critics of religious democracy should be studied. In order to transfer the obtained contents into a computer game, website, wiki, cellphone software, and other forms of digital media, a lot of money should be invest in this part. These contents should be in Arabic and Persian languages in order to use them a lot in our life.

\section{Discussion}

Based on the statistics, the amount of human being technical information becomes twice every two years. Now, this statistics is reached to 72 hours. 3000 new books are published in the world every day. A value of New York Times one-week or eight day information is more than all the information that one person access during his or her life in the eighteenth century. Now, a number of SMS is equal to the population of all the world. World is always experiencing a new thing. This scientific variation had a lot of consequences for other dimensions of human beings' lives specially, in the domain of political and social and made a new era for people in the future. Statistics shows that a number of internet users of developing countries are developing very fast. Maybe, a government's non-attendence in the virtual spaces is a first thing that attracts people's attention. A second thing is that thinkers of our country do not attend in these virtual spaces. In web 3, we can interact with thousands of small and big communities and millions of people directly. Thinkers of western countries are always in the virtual spaces, but thinkers and politicians of Iran are not always in the virtual spaces. Scientific pages of most universities are not up to dated and not in an English language which is the main language of the world. We can make thinkers of the world and specially, students of the targeted communities familiar with the religious democracy through making scientific and political groups and free networks like face book, Wikipedia, twitter, and so on.

In the next steps, we can design applied and attractive software on the platform of these networks and make the environment of sub-networks more applicable and attractive and attract more people to these networks.

Political issues, scientific works, political and religious sources and every activities in the framework of these networks are introduced in conferences, meetings, and working groups. Since there are no limitations for making sub-networks, we can make different networks for audiences of different ages, religions, and perspectives.

\section{Conclusion}

We live in digital era. Digital media have an effective role on sharing information among people. The media which have dominated all the domains of human beings' lives have introduced a digital human being. Nowadays, digital technolo- 
gies not only develop economy, politics, culture, emotions, social relations, and our points of view, but also it is referred to things which are of universal digital or electronic features.

With regard to the main and effective role of modern media, media are good tools for flourishing the talents and capabilities of politicians and thinkers. This technology is not strange for our country. Therefore, political institutions such as ministry of foreign affairs, university institutions, and religious institutions should strengthen their points of view toward information technology and modern media.

Western countries and statesmen use these digital media for stating their principles and strategies in order to be in line with these media. A duty of statesmen are to plan and use mass and digital communication media like internet, social networks, computer games, and social networks of cellphone in order to transfer a discussion about religious democracy into one of the well-known and universal discussions. In fact, it should be stated that expanding discourse plans with the use of digital media internally and internationally can be effective in the development of discussing about the religious democracy and can be a good tool for encountering with the enemies' political attacks.

Digital media can be used for stating the principles of democracy and creating the economic and developmental grounds. Therefore, digital media can develop the country from political way. With regard to the high importance of digital media in the present world and people's lives and a religious democracy as a political system of Iran, it is necessary to study the role of digital media in the universities and scientific centers toward giving information about the universal religious democracy, their application in the discourse processes, and their weakness facing with the religious democracy approach.

\section{References}

Ameli, S. R. (2003). Globalization and the International Community Anxiety. Social Sciences, 21, 143-174.

Ameli, S. R. (2010). Critical Studies of Virtual Colonization of America: Soft Power and Virtual Empires. Tehran: Amirkabir Press.

Azimi Fard, F. (2013). Globalization of Media. Journal of Life Style, 3, 3-45.

Basirian, H., \& Basirian, R. (2006). An Introduction to Media Literacy and Critical Thinking. Media Journal, 4, 33-50.

Bell, D. (2001). An Introduction to Cyberculture (p. 25). Abingdon-on-Thames: Routledge.

Giddens, A. (2000). Abandoned World. Tehran: Science and Literature.

Holmes, D. (2005). Communication Theory, Media, Technology and Society. London: Sage Publications.

Laughey, D. (2007). Key Themes in Media Theory. New York, NY: McGraw Hill Publication.

Mac Koyl, D. (2003). Introduction to Mass Communication Theory. Tehran: Media Research Center. 
Moraveji, S., \& Zarei, F. (2012). Digital Media and Health. Tehran: Sobhan Press.

Motamednejad, K. (2012). Database: Fundamental Ideas, Critical Insights, and Global Perspectives. Tehran: Communication Research Center Press.

Niko. (2002). Understanding the TV Audience with the Approach of Uses and Gratifications. Tehran: Soroush Press.

Taghdisi, M. H. (2014). Cultural Engineering of Virtual Space. The Supreme Council of Cultural Revolusion.

Submit or recommend next manuscript to SCIRP and we will provide best service for you:

Accepting pre-submission inquiries through Email, Facebook, LinkedIn, Twitter, etc. A wide selection of journals (inclusive of 9 subjects, more than 200 journals)

Providing 24-hour high-quality service

User-friendly online submission system

Fair and swift peer-review system

Efficient typesetting and proofreading procedure

Display of the result of downloads and visits, as well as the number of cited articles Maximum dissemination of your research work

Submit your manuscript at: http://papersubmission.scirp.org/

Or contact ojps@scirp.org 